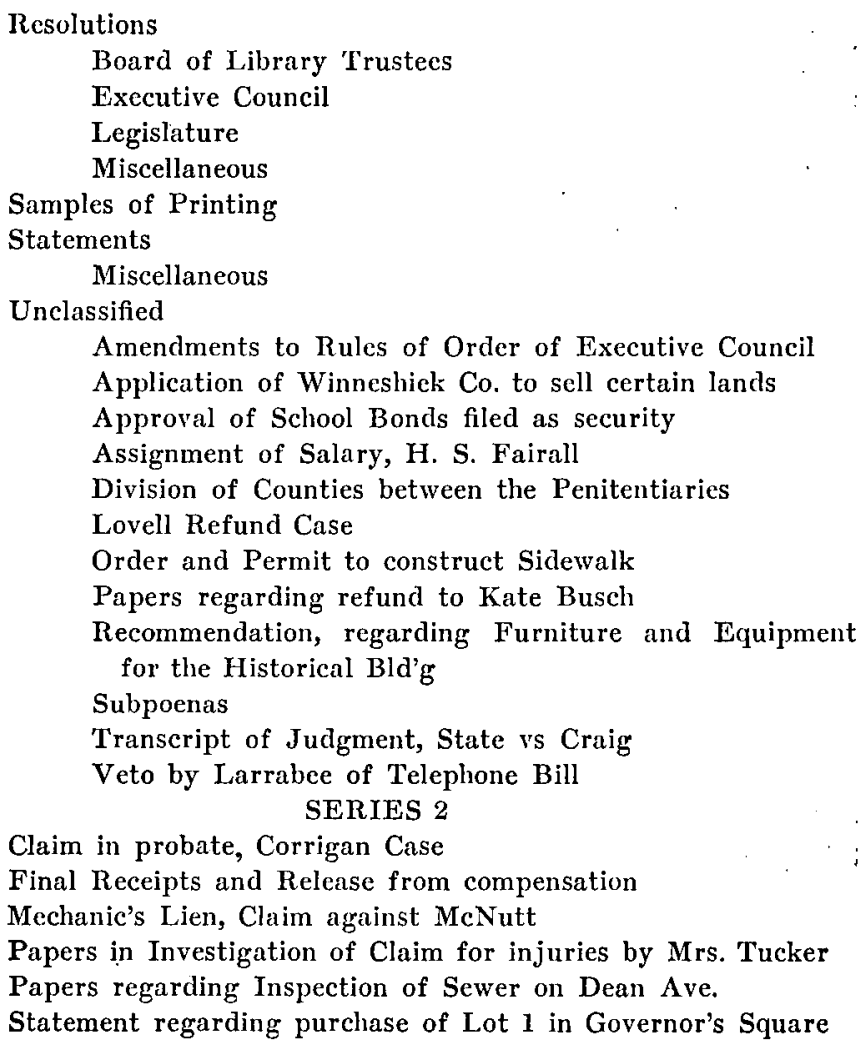

\title{
FIRST BICYCLE WEST OF MISSISSIPPI
}

Velocipedes: We learn that our fellow townsman, B. F. Allen and C. P. Luse, have each ordered a velocipede for their own use. All right! Des Moines being the fastest city in the state, ought to have the first bicycle; and we did have a little ambition of our own to live in history as being the first chap who brought a bicycle west of the Mississippi, but we haven't got it now as bad as we had. Anyhow we don't envy you fellows the bumps and tumbles and laughs you'll get.-Daily State Register, Des Moines, Iowa, Jan. 20,1869 . (Thought to have been written by Ret Clarkson.-Ed.) (In the Newspaper Division of the Historical, Memorial and Art Department. 
Copyright of Annals of Iowa is the property of State of Iowa, by \& through the State Historical Society of Iowa and its content may not be copied or emailed to multiple sites or posted to a listserv without the copyright holder's express written permission. However, users may print, download, or email articles for individual use. 